Henri Collomb (Dakar)

Rogclio Diaz-Guerrero (Mexico)

'T. A. Lambo (Ibadan)

Lamaimas Saradatta (Bangkok)

Herbert C. Kelman (Michigan)
An approach to the notion of role status and interpersonal relations in Africa.

Socio-psychological research in Mexico: some problems and preliminary results.

New concepts in social-psychiatric research in Africa.

Social-psychological research in Thailand: needs and problems.

Some ideological dimensions basic to social change in developing countries.

\title{
Agreement of African Research Institutes and the Development Centre of the OECD on a Co-operative Research Project
}

Following a proposal made at the second meeting of the Directors of Economic Development Institutes, held in Paris on 14 and is May 1964, it was agreed that the Development Centre of the OECD and four African Research Institutes (the Nigerian Institute of Social and Economic Research at Ibadan, l'Institut de Science Économique Appliquée at Dakar, l'Institut de Recherches Économiques et Sociales at Leopoldville, and the East African Institute of Social Research at Kampala), should co-operate on a joint research programme on industrialization in sub-Saharan Africa, a study of which, it is hoped, will be completed in 1966.

The study will deal with two major aspects of industrialization: first, the problem of location of industries in the framework of alternative schemes on economic integration on a national and interregional basis; second, the interdependence of new industrial projects and their input requirements, emphasis also being given to the question of the size of firms and the mix of output in view of the market conditions in those regions. Each participating institute will be free to carry out its investigations in the manner most appropriate to its own region. A detailed account of the projects of the participants is to appear in the forthcoming issue of the Liaison Bulletin.

The Development Centre has made arrangements for strengthening the research teams of the participating institutes by providing ad hoc research assistants. At a later stage, on the basis of the institutes' contributions, the Centre will attempt an analytical synthesis of the process of industrialization in Africa. It is envisaged that the individual contributions will be published together in a single volume.

\section{'African Forum'}

THE first number of African Forum: A Quarterly Journal of Contemporary Affairs has been published by the American Society for African Culture. In an Editorial Statement Dr. John A. Davis, Professor of Political Science at the City College, New York, and President of the society, recalls its founding following the First World Conference of Negro Writers and Artists in Paris in September 1956. African Forum will, like the society, concern itself with the political, social, and economic aspects of the new African nations, and its contributors will be those who have been involved in the process of solving problems arising from these developments-in many cases Africans and Americans of African descent. There will also be features dealing with cultural development and the contribution of African and American Negro poets and writers, and the problems of national minorities and inter-group adjustment.

Contributors to the first number include Nnamdi Azikwe, Jomo Kenyatta, and Julius K. Nyerere on aspects of African unity, Peter Duignan with a bibliographic essay on PanAfricanism, and Cecile McHardy on the performing arts in Ghana. There is also an extensive book-review section. 